\title{
Tribuna. Corumbá, 27.04.1943 Pedro de Medeiros, por Lobivar de Matos
}

$\mathrm{C}$ orria o ano de 1925, Corumbá vivia, politicamente, a sua vidinha agitada. Pedro de Medeiros era, então uma espécie de "leader" popular, conhecido em todas as bibocas da cidade. Em todas as reivindicações populares era a voz de comando, o vulto ereto, o espírito coordenador, orientando a massa que apreciava e o abandonava na primeira esquina. Reclamava contra toda e qualquer manobra que visasse encarecer a vida da população já sacrificada. Lembro-me bem das suas passeatas, dos seus comícios dos seus boletins inflamados! Era garoto e já me entusiasmava com aquelas coisas todas, principalmente quando ouvia o Medeiros falar em público ou o enxergava à frente do povo. Certa ocasião, os padeiros e os açougueiros propalavam o firme propósito de aumentar o preço do pão e da carne. Foi o bastante. Pedro de Medeiros reuniu o povo na esquina do Jardim e depois de, como tribuno popular agitá-lo freneticamente, manobrou-o e o conduziu de padaria em padaria e de açougue em açougue num protesto que tinha muito de rebelião. Se não me engano, a minha simpatia por ele data desta época.

A minha geração não poderá esquecer facilmente Pedro de Medeiros, principalmente aquele Pedro simples, bom, que se metia em nossos folguedos, e como qualquer um de nós, soltava pandorga ou jogava bolita nas ruas e praças. Nos sábados de aleluia, então, era um prazer a gente percorrer os "Judas" da rua Tiradentes, porque idealizados e confeccionados por ele. Com a veia satírica que 
jamais o abandonou, vingava-se dos bolicheiros que lhe negavam crédito e os caracterizava perfeitamente naqueles bonecos que nós dependurávamos nos postes, e após o toque de aleluia, arrastávamos até a beira do rio numa luta simbólica contra os eternos traidores de todas as classes e de todos os tempos.

O tempo passa. Mais tarde, muitos anos depois, fomos nos encontrar numa barca, numa daquelas barcas que levam os cariocas para as diversas ilhas da Guanabara. E durante toda a travessia foi uma conversa só: poesia. Ele recitava suas últimas produções poéticas com aquele seu modo especial de dizer as coisas que tocam o coração. Embora eu não suportasse, já naquela época, a poesia montanhosa ou o soneto metrificado horrivelmente a rigor, Pedro de Medeiros me comoveu e me prendeu mais de uma hora em seu espírito vivo e em seus sentimentos profundamente humanos. Tempo depois quando me defini na poesia e penetrei a corrente chamada modernista, ele continuou firme na velha escola literária e já então me condenava, entre os seus amigos, pelo grave erro de não metrificar as minhas coisas. Soube disso e lamentei, também entre amigos, que o juízo de Pedro de Medeiros fosse tal, pois eu o compreendia na sua velha arte e na sua velha escola. Coisas do espírito humano! E todas as vezes que, face a face, tocávamos nesse assunto, ela dava a sua definição sobre poesia, certa, mas unilateral. Discutíamos levemente e passávamos para outras matérias. Espírito sutil de ironista e de poeta romantico e sentimental, Pedro de Medeiros deixou uma produção poética que deve ser reunida e publicada para que não caia no esquecimento e no indeferentismo da nossa época.

Nunca tive maior intimidade com Pedro de Medeiros. Não só porque ele pertencia a uma geração que não entendia a minha como também devido a diferença de nossa idade. E para mim foi o maior consolo, quando de volta à minha terra passei a ferir em cheio problemas locais e tive dele apoio integral. Por varias vezes me procurou na redação deste jornal para me aplaudir e para me incentivar a atacar certas manobras indecorosas. Entusiasmado com o efeito contundente de meus tópicos, já nos seus últimos dias, vinha apoiado em sua inseparável bengala, trazer-me um assunto novo ou mesmo tópicos escritos por ele mesmo, visando ora uma coisa ora outra. E eu via nisso nada mais nada me- 
nos do que o seu grande amor pela cidade e pelo nosso povo. Eu nunca o vi tão furioso quando a Prefeitura escreveu aquela carta, abatendo para três dias o sete em que a população pobre ficou sem água.

Agora, chegou-me a noticia de sua morte. E eu, em homenagem ao grande boêmio, filósofo e poeta que ele foi, espírito esclarecido, "leader" do nosso povo só posso fazer uma coisa: sugerir por intermédio de TRIBUNA, ao povo de Corumbá, uma "herma" a Pedro de Medeiros, ao poeta Pedro de Medeiros, ao jornalista Pedro de Medeiros. Porque essa será a maior homenagem que poderemos prestar-lhe depois de sua morte. Que o povo de Corumbá se cotize, entre si, e levante ali na rua Tiradentes, bem frente à sua casa (ele chamava-se de tugurio) onde ele viveu os últimos dias a se deleitar com o colorido gostoso que os "flamboyants" derramavam sobre a praça ao cair da tarde ou ao amanhecer.

(Pedro de Medeiros faleceu em 12 de abril de 1943) 